\title{
Perilaku Petani dalam Menerapkan Teknologi BP3T (Bakteri Perakaran Pemacu Pertumbuhan Tanaman) Pupuk Kandang untuk Tanaman Kakao di Kabupaten Limapuluh Kota
}

\section{Farmer Behavior in Implementing BP3T Manure Technology for Cocoa Plant in Limapuluh Kota Regency}

\author{
Haliatur Rahma ${ }^{1}$, Sri Wahyuni ${ }^{1}$, Jumsu Trisno ${ }^{1}$, Martinius ${ }^{1}$, Rita Noveriza ${ }^{2}$ \\ ${ }^{1}$ Fakultas Pertanian Universitas Andalas, Padang 25163, Indonesia \\ ${ }^{2}$ Balai Penelitian Rempah dan Obat, Bogor 16124, Indonesia
}

\begin{abstract}
Vascular streak dieback (VSD) is a deadly disease of cocoa because it attacks the vascular tissue growing point. RGBGP Technology (Root Growth Based Growth Plants) manure is designed to help control the disease while helping grow cocoa plants. This research aims to examine the behavior of cocoa farmers in applying RGBGP technology package of manure that is allegedly formed due to individual characteristics and innovation characteristics. This research was designed descriptively qualitative located in Limapuluh Kota District. Sampling was conducted by census, 43 people belonging to 4 selected farmer groups, namely Aroma, Inovasi, Buah Lobek, and Maju Sejahtera. The results show that farmers' behavior generally shows the willingness to implement RGBGP package of manure in the long term, supported by the relative advantages of innovation, accessible resources, easy to do and applied technology, observable results, and no significant constraints. However, attitudes are not related to individual characteristics of farmers consisting of formal education, nonformal education, experience of farming, land status, land area, main occupation, and gender.
\end{abstract}

Keywords: Cocoa, Innovation, Individual Characteristics, Innovation Characteristics

\begin{abstract}
Abstrak
Vascular streak dieback (VSD) merupakan penyakit mematikan kakao karena menyerang jaringan pembuluh titik tumbuh. Teknologi BP3T (Bakteri Perakaran Pemacu Pertumbuhan Tanaman) pupuk kandang dirancang untuk membantu mengendalikan penyakit tersebut sekaligus membantu pertumbuhan tanaman kakao. Penetian ini bertujuan untuk mengkaji perilaku petani kakao dalam menerapkan paket teknologi BP3T pupuk kandang yang diduga terbentuk karena karakteristik individu dan karakteristik inovasi. Penelitian ini dirancang secara deskriptif kualitatif yang berlokasi di Kabupaten Limapuluh Kota. Pengambilan sampel dilakukan secara sensus, yaitu 43 orang yang tergabung ke dalam 4 kelompok tani terpilih, yaitu Kelompok Tani Aroma, Kelompok Tani Inovasi, Kelompok Tani Buah Lobek, dan Kelompok Tani Maju Sejahtera. Hasil penelitian adalah perilaku petani umumnya menunjukkan sikap ingin menerapkan paket teknologi BP3T pupuk kandang dalam jangka panjang, didukung oleh keuntungan relatif inovasi, sumberdaya yang mudah diakses, teknologi mudah dikerjakan dan diterapkan, hasil dapat diamati, dan tidak ada kendala berarti. Namun, sikap tidak berhubungan dengan karakteristik individu petani yang terdiri atas pendidikan formal, pendidikan nonformal, pengalaman berusahatani, status lahan, luas lahan, pekerjaan utama, dan jenis kelamin.
\end{abstract}

Kata Kunci: Inovasi, Kakao, Karakteristik Individu, Karakteristik Inovasi

\footnotetext{
${ }^{1}$ Korespondensi penulis

E-mail: haliatur_rahma@yahoo.com
} 


\section{Pendahuluan}

Jumlah konsumsi kakao yang meningkat setiap tahun di seluruh dunia membuat kakao memiliki peran strategis dalam sektor perkebunan, sehingga di Indonesia kakao menjadi salah satu komoditas perkebunan andalan bagi pendapatan nasional dan devisa negara. Sumatera Barat sebagai salah satu daerah dengan kualitas kakao terbaik di Indonesia menjadikan kakao sebagai salah satu komoditas perkebunan yang peranannya cukup penting bagi perekonomian daerah. Penghasilan tanaman jenis kakao di Sumatera Barat sudah cukup membanggakan dengan luas tanaman kakao di Sumbar yang mencapai 150 hektare (Ha) lebih, per tahunnya Sumbar bisa menghasilkan kakao dengan berat sekitar 83 ribu ton.

Permasalahan yang dihadapi petani kakao salah satunya adalah penyakit vascular streak dieback (VSD) yang merupakan penyakit mematikan karena menyerang jaringan pembuluh titik tumbuh. Penyakit VSD pertama kali ditemukan pada tahun 1983 di Pulau Sebatik (Kalimantan Timur), dan pada tahun 2013 hampir semua pertanaman kakao terinfeksi penyakit tersebut (Harni dan Khaerati, 2013; Dhana et al. 2013). Di Sumatera Barat, penyakit ini pertama kali dilaporkan pada tahun 2015 dengan insidensi $58,82 \%$ - 100\% dan intensitas 24,29\% 44,7\% (Trisno et al., 2016). Hasil survei dan wawancara dengan petani di Kabupaten Padang Pariaman dan Kabupaten Limapuluh Kota, banyak kebun-kebun kakao yang sudah dimusnahkan dan diganti dengan tanaman lain karena adanya penyakit yang menyebabkan daun-daun gugur, tanaman gundul dan tidak lagi menghasilkan. Di sisi lain, perawatan kebun yang kurang baik dapat mempercepat penyebaran penyakit di lapang.

Salah satu cara yang dilakukan untuk menanggulangi penyakit ini adalah dengan pemanfaatan bakteri perakaran untuk peningkatan ketahanan tanaman. Besarnya potensi dari Bakteri Perakaran Pemacu Pertumbuhan Tanaman (BP3T) seperti P. flourescen, Basillus sp dan Serratia marsescens dalam meningkatkan ketahanan tanaman terhadap berbagai patogen tanaman, sehingga penggunaannya dimungkinkan juga dapat meningkatkan ketahanan tanaman kakao terhadap penyakit VSD. Di sisi lain, pemanfaatan pestisida nabati dari tanaman serai wangi dapat dimanfaatkan untuk membatasi penyebaran spora jamur penyebabnya. Tanaman serai wangi dilaporkan merupakan salah satu pestisida nabati yang potensial untuk mengendalikan patogen tumbuhan (Mariana dan Noveriza, 2013), sehingga dapat meningkatkan kemampuannya dalam mengendalikan atau menekan perkembangan patogen penyebab penyakit VSD. Hasil penelitian di Kabupaten Lima Puluh Kota, formula BP3T campuran (5 $\mathrm{kg} /$ pohon) menunjukkan efektifitas dalam ukuran panjang buah $1400 \%$, diameter buah $316,7 \%$, jumlah tunas $216,13 \%$ dan jumlah buah sebesar 925\% dengan rata efektifvitas sebesar 714,46\%, sedangkan Paket formula BP3T-pupuk kandang sapi dan nano pestisida serai wangi memiliki rata-rata efektivitas sebesar 198,86\%.

Transfer teknologi perlu dilakukan untuk mendiseminasikan paket teknologi BP3T pupuk kandang dan nano pestisida serai wangi dalam menanggulangi penyakit VSD kepada petani kakao melalui kegiatan pelatihan. Kegiatan pelatihan dibutuhkan untuk mengatasi diskrepansi petani yang mulanya tidak memahami inovasi yang diberikan, di mana dalam hal ini berupa paket teknologi BP3T pupuk kandang dan nano pestisida serai wangi, sehingga akhirnya diharapkan dapat mengubah perilaku petani dalam penanganan penyakit VSD pada tanaman kakao. Sarwono (1993) menyebutkan bahwa perilaku merupakan hasil dari segala macam pengalaman serta interaksi seseorang dengan lingkungan yang terwujud dalam bentuk pengetahuan, sikap dan tindakan yang merupakan respon atau reaksi seseorang individu terhadap rangsangan yang berasal dari dalam maupun dari luar dirinya, seperti metode penyuluhan dan karakteristik inovasi itu sendiri. 
Sementara itu, Lewin dalam Azwar (2000) menyatakan bahwa perilaku adalah fungsi karakteristik individu dan lingkungan. Sejalan dengan hal tersebut, perubahan perilaku yang diharapkan terbentuk melalui pelatihan teknologi BP3T pupuk kandang adalah bertambahnya pengetahuan petani mengenai teknologi tersebut, munculnya keinginan untuk menguji coba dalam skala kecil pada lahan kakao, dan tindakan kolektif berupa adopsi paket teknologi secara keseluruhan pada lahan kakao petani. Perubahan perilaku tersebut salah satunya diduga terbentuk karena faktor dari dalam diri petani yaitu karakteristik individu dan faktor dari luar yaitu karakteristik inovasi dan metode penyuluhan. Berdasarkan permasalahan tersebut, salah satu pendekatan untuk melihat penerapan paket teknologi BP3T pupuk kandang oleh petani kakao adalah dengan mengkaji perilaku petani kakao yang diduga terbentuk karena karakteristik individu dan karakteristik inovasi.

\section{Metode Penelitian}

Penelitian ini dirancang secara deskriptif kuantitatif menggunakan metode survei. Lokasi penelitian dipilih secara purposif, yaitu lahan petani kakao terserang penyakit VSD di Sentra Pertanaman Kakao di Kabupaten Lima Puluh Kota Propinsi Sumatera Barat. Waktu penelitian bulan dari bulan Februari - Desember 2018.

Populasi penelitian adalah petani kakao yang terserang penyakit VSD di Kabupaten Lima Puluh Kota. Pengambilan sampel dilakukan secara sensus, yaitu 43 orang yang tergabung ke dalam 4 kelompok tani terpilih, yaitu Kelompok Tani Aroma, Kelompok Tani Inovasi, Kelompok Tani Buah Lobek, dan Kelompok Tani Maju Sejahtera. Jenis data yang dikumpulkan pada penelitian ini terdiri dari data primer yang diperoleh melalui wawancara menggunakan kuesioner dan data sekunder diperoleh dari Dinas Pertanian, Balai Penyuluhan Pertanian dan Badan Pusat Statistik. Analisis data penelitian dilakukan dengan menggunakan analisis statitistik deskriptif untuk medeskripsikan karakteristik petani kakao dan karakteristik inovasi teknologi BP3T pupuk kandang untuk pengendalian penyakit VSD; dan uji statistik inferensia untuk menganalisa hubungan karakteristik petani dengan karakteristik inovasi teknologi BP3T Pupuk Kandang. Uji statistik inferensia menggunakan analisa chi square dan korelasi rank Spearman. Uji statistik deskriptif dan uji statistis inferensia dilakukan dengan menggunakan software SPSS 23.00.

\section{Hasil dan Pembahasan}

\section{Karakteristik Individu Petani Kakao}

Karakteristik petani adalah ciri yang melekat pada diri petani, seperti umur, tingkat pendidikan formal, tingkat pedidikan nonformal, pekerjaan, pengalaman berusaha tani, status kepemilikan lahan, luas lahan, dan jenis kelamin. Karakteristik setiap petani umumnya berbeda-beda. Tabel 1 memperlihatkan distribusi karakteristik individu petani kakao di Kabupaten Limapuluh Kota berdasarkan kelompok tani terpilih, yaitu Kelompok Tani Inovasi, Kelompok Tani Buah Lobek, dan Kelompok Tani Maju Sejahtera.

Tabel 1 memperlihatkan bahwa pada keempat kelompok tani terpilih; Kelompok Tani Aroma, Kelompok Tani Inovasi, Kelompok Tani Buah Lobek, dan Kelompok Tani Maju Sejahtera; umumnya terdiri atas petani dengan usia dewasa (30-49 tahun), memiliki tingkat pendidikan formal tinggi (SMA Perguruan Tinggi), akan tetapi umumnya mengikuti pendidikan non formal seperti kegiatan pelatihan pada kategori rendah (1-2 kali). Hasil wawancara di lapangan menunjukkan bahwa beberapa jenis kegiatan pelatihan yang pernah diikuti oleh anggota antara lain adalah pelatihan budidaya kakao, dan pelatihan pembuatan teknologi formula BP3T-pupuk kandang sapi dan nano pestisida. Selanjutnya, pengalaman berusahatani kakao anggota kelompok umumnya tergolong rendah, yaitu berkisar 
antara 1-10 tahun, meskipun ada yang lebih lama dengan melanjutnya usahatani milik orang tua dengan rata-rata kepemilikan lahan merupakan milik sendiri dengan luas lahan umumnya berada pada kategori sempit, yaitu $0.2-0.7$ ha.

Selain itu, Tabel 1 juga memperlihatkan bahwa tidak semua petani pada masingmasing kelompok tani memiliki pekerjaan utama sebagai petani kakao. Petani pada Kelompok Tani Inovasi dan Kelompok Tani Buah Lobek sebagian besar memiliki pekerjaan utama di luar bertani kakao, seperti menjadi buruh harian, sawah, dan sebagainya. Selanjutnya, sebagian besar petani pada Kelompok Tani Aroma merupakan laki-laki, sedangkan sebagian besar petani di kelompok tani Buah Lobek dan Maju Sejahtera adalah perempuan.

\section{Karakteristik Inovasi Paket Teknologi BP3T Pupuk Kandang pada Kelompok Tani di Kabupaten Limapuluh Kota}

Menurut Rogers (2013) karakteristik inovasi terdiri atas keuntungan relatif, tingkat kesesuaian, tingkat kerumitan Inovasi, tingkat kemudahan, dan tingkat keteramatan inovasi. Tabel 2 memperlihatkan distribusi karakteristik inovasi paket teknologi BP3T pupuk kandang dan nano pestisida serai wangi pada kelompok tani di Kabupaten Limapuluh Kota.

Tabel 1. Distribusi karakteristik individu petani kakao pada kelompok tani di Kabupaten Limapuluh Kota

\begin{tabular}{|c|c|c|c|c|c|c|c|c|c|}
\hline \multirow{2}{*}{\multicolumn{2}{|c|}{ Karakteristik Individu }} & \multicolumn{4}{|c|}{ Frekuensi (jumlah orang) } & \multicolumn{4}{|c|}{ Persentase (\%) } \\
\hline & & \multirow[t]{2}{*}{ Aroma } & \multirow[t]{2}{*}{ Inovasi } & \multirow[t]{2}{*}{$\begin{array}{c}\text { Buah } \\
\text { Lobek }\end{array}$} & \multirow[t]{2}{*}{$\begin{array}{c}\text { Maju } \\
\text { Sejahtera }\end{array}$} & \multirow[t]{2}{*}{ Aroma } & \multirow[t]{2}{*}{ Inovasi } & \multirow[t]{2}{*}{$\begin{array}{c}\text { Buah } \\
\text { Lobek }\end{array}$} & \multirow[t]{2}{*}{$\begin{array}{c}\text { Maju } \\
\text { Sejahtera }\end{array}$} \\
\hline 1. & Umur & & & & & & & & \\
\hline & Muda (<30 tahun) & 0 & 0 & 0 & 0 & 0 & 0 & 0 & 0 \\
\hline & Dewasa (30-49 tahun) & 7 & 6 & 9 & 6 & 58.3 & 75.0 & 75.0 & 54.5 \\
\hline & Tua ( $\geq 50$ tahun) & 5 & 2 & 3 & 5 & 41.7 & 25.0 & 25.0 & 45.5 \\
\hline \multicolumn{10}{|c|}{ 2. Tingkat Pendidikan Formal } \\
\hline & Rendah (SD) & 1 & 1 & 3 & 0 & 8.3 & 12.5 & 25.0 & 0 \\
\hline & Sedang (SMP) & 5 & 4 & 4 & 2 & 41.7 & 50.0 & 33.3 & 18.2 \\
\hline & $\begin{array}{l}\text { Tinggi (SMA- } \\
\text { Perguruan Tinggi) }\end{array}$ & 6 & 3 & 5 & 9 & 50.0 & 37.5 & 41.7 & 81.8 \\
\hline \multicolumn{10}{|c|}{ 3. Pendidikan Non Formal } \\
\hline & Rendah (1-2) & 8 & 2 & 10 & 8 & 66.7 & 25.0 & 83.3 & 72.7 \\
\hline & Sedang (3-4) & 1 & 3 & 2 & 3 & 8.3 & 37.5 & 16.7 & 27.3 \\
\hline & Tinggi (5-6) & 3 & 3 & 0 & 0 & 25.0 & 37.5 & 0 & 0 \\
\hline \multicolumn{10}{|c|}{ 4. Pengalaman Berusahatani } \\
\hline & Rendah (1 - 10 tahun) & 10 & 3 & 2 & 9 & 83.3 & 37.5 & 16.7 & 81.8 \\
\hline & Sedang (11 - 20 tahun) & 2 & 5 & 5 & 1 & 16.7 & 62.5 & 41.7 & 9.1 \\
\hline & Tinggi (21 - 30 tahun) & 0 & 0 & 5 & 1 & 0 & 0 & 41.7 & 9.1 \\
\hline \multicolumn{10}{|c|}{ 5. Pekerjaan Utama } \\
\hline & $\begin{array}{l}\text { Lainnya (bukan petani } \\
\text { kakao) }\end{array}$ & 5 & 5 & 5 & 8 & 41.7 & 62.5 & 41.7 & 72.7 \\
\hline & Petani kakao & 7 & 3 & 7 & 3 & 58.3 & 37.5 & 58.3 & 27.3 \\
\hline \multicolumn{10}{|c|}{ 6. Status Lahan } \\
\hline & Milik Sendiri & 12 & 8 & 12 & 10 & 100.0 & 100.0 & 100.0 & 90.9 \\
\hline & Sewa & 0 & 0 & 0 & 1 & 0 & 0 & 0 & 9.1 \\
\hline \multicolumn{10}{|c|}{ 7. Luas Lahan } \\
\hline & Sempit $(0.2-0.7$ ha $)$ & 10 & 6 & 7 & 7 & 83.3 & 75.0 & 58.3 & 63.6 \\
\hline & Sedang (0.8 - 1.3 ha) & 2 & 1 & 3 & 3 & 16.7 & 12.5 & 25.0 & 27.3 \\
\hline & Luas (1.4 - 2 ha) & 0 & 1 & 2 & 1 & 0 & 12.5 & 16.7 & 9.1 \\
\hline \multicolumn{10}{|c|}{ 8. Jenis Kelamin } \\
\hline & Laki-laki & 7 & 4 & 2 & 1 & 58.3 & 50.0 & 16.7 & 9.1 \\
\hline & Perempuan & 5 & 4 & 10 & 10 & 41.7 & 50.0 & 83.3 & 90.9 \\
\hline & Jumlah & 12 & 8 & 12 & 11 & & & & 100.0 \\
\hline
\end{tabular}


Tabel 2. Distribusi karakteristik inovasi paket teknologi BP3T pupuk kandang dan nano pestisida serai wangi pada kelompok tani di Kabupaten Limapuluh Kota

\begin{tabular}{|c|c|c|c|c|c|c|c|c|c|}
\hline \multirow{2}{*}{\multicolumn{2}{|c|}{$\begin{array}{c}\text { Frekuensi } \\
\text { Karakteristik } \\
\text { Inovasi Pupuk } \\
\end{array}$}} & \multicolumn{4}{|c|}{ Frekuensi (jumlah orang) } & \multicolumn{4}{|c|}{ Persentase (\%) } \\
\hline & & \multirow[t]{2}{*}{ Aroma } & \multirow[t]{2}{*}{ Inovasi } & \multirow[t]{2}{*}{$\begin{array}{c}\text { Buah } \\
\text { Lobek }\end{array}$} & \multirow[t]{2}{*}{$\begin{array}{c}\text { Maju } \\
\text { Sejahtera }\end{array}$} & \multirow[t]{2}{*}{ Aroma } & \multirow[t]{2}{*}{ Inovasi } & \multirow[t]{2}{*}{$\begin{array}{c}\text { Buah } \\
\text { Lobek }\end{array}$} & \multirow[t]{2}{*}{$\begin{array}{c}\text { Maju } \\
\text { Sejahtera } \\
\end{array}$} \\
\hline 1. & $\begin{array}{l}\text { Keuntungan } \\
\text { relatif }\end{array}$ & & & & & & & & \\
\hline & Tidak Tahu & 1 & 0 & 1 & 3 & 8.3 & 0 & 8.3 & 27.3 \\
\hline & Tahu & 11 & 8 & 11 & 8 & 91.7 & 100.0 & 91.7 & 72.7 \\
\hline \multirow[t]{3}{*}{2.} & $\begin{array}{l}\text { Tingkat } \\
\text { kesesuaian } \\
\text { inovasi }\end{array}$ & & & & & & & & \\
\hline & Tidak tersedia & 0 & 0 & 0 & 0 & 0 & 0 & 0 & 0 \\
\hline & Tersedia & 12 & 8 & 12 & 11 & 100.0 & 100.0 & 100.0 & 100.0 \\
\hline \multirow[t]{3}{*}{3.} & $\begin{array}{l}\text { Tingkat } \\
\text { kemudahan } \\
\text { inovasi }\end{array}$ & & & & & & & & \\
\hline & Mudah & 12 & 8 & 12 & 11 & 100.0 & 100.0 & 100.0 & 100.0 \\
\hline & Sulit & 0 & 0 & 0 & 0 & 0 & 0 & 0 & 0 \\
\hline \multirow[t]{3}{*}{4.} & $\begin{array}{l}\text { Tingkat } \\
\text { keteramatan } \\
\text { inovasi }\end{array}$ & & & & & & & & \\
\hline & Tidak Baik & 0 & 0 & 0 & 3 & 0 & 0 & 0 & 27.3 \\
\hline & Baik & 12 & 8 & 12 & 8 & 100.0 & 100.0 & 100.0 & 72.7 \\
\hline \multirow[t]{4}{*}{5.} & Kendala inovasi & & & & & & & & \\
\hline & Tidak Ada & 5 & 6 & 5 & 6 & 41.7 & 75.0 & 41.7 & 54.5 \\
\hline & Ada & 7 & 2 & 7 & 5 & 58.3 & 25.0 & 58.3 & 45.5 \\
\hline & Total & 12 & 8 & 12 & 11 & 100.0 & 100.0 & 100.0 & 100.0 \\
\hline
\end{tabular}

Berdasarkan Tabel 2, petani umumnya mengetahui manfaat paket teknologi formula BP3T-pupuk kandang sapi yang dilakukan selama pelatihan, yaitu beberapa di antaranya adalah pertumbuhan menjadi lebih baik, munculnya tunas-tunas daun baru, daun kuning menjadi hijau dan mengilat, serta memacu pertumbuhan bunga dan putik kakao. Selain itu, keuntungan yang diperoleh petani adalah biaya pemupukan kakao per batang dengan menggunakan teknologi BP3T-pupuk kandang sapi lebih rendah dibandingkan dengan biaya pemupukan menggunakan pupuk kandang biasa dan pupuk kimia sintetis. Hasil analisis usahatani berdasarkan data di lapangan didapatkan bahwa saat menggunakan pupuk kimia sintetis, petani minimal harus mengeluarkan dana sebesar Rp. 5000,00 per batang kakao hingga Rp. 27.500. Sedangkan jika menggunakan pupuk BP3T, petani hanya menggunakan biaya sebesar Rp. 3.514,00 per batang kakao. Hal tersebut jelas lebih menguntungkan petani dibandingkan harus menggunakan pupuk kimia sintetis. Hasil di lapangan menunjukkan bahwa sumberdaya yang dibutuhkan untuk membuat formula BP3T pupuk kandang sapi tersedia dan cukup mudah dicari. Selanjutnya, anggota kelompok tani menyebutkan bahwa tidak sulit bagi petani dalam membuat formula BP3T pupuk kandang tersebut, terutama jika dilakukan berkelompok. Beberapa petani hanya merasa kesulitan jika harus membuat sendiri, sebab terkendala dalam mengaduk pupuk kandang dengan fermentasi air kelapa dengan bakteri yang dirasa berat. Selain itu, beberapa kendala lain yang dirasakan oleh petani adalah agak sulit menemukan air kepala dalam jumlah banyak.

Meskipun demikian, umumnya petani kakao di Kabupaten Limapuluh Kota memiliki keinginan untuk menerapkan teknologi formula BP3T pupuk kandang untuk lahan mereka sendiri. Hal ini disebabkan karena keuntungan yang didapatkan, yaitu tanaman kakao menjadi lebih baik, mengurangi 
penyakit VSD yang rentan menyerang tanaman kakao petani, dan merangsang pertumbuhan tunas daun baru serta bunga baru yang kemudian tumbuh menjadi putik dan buah. Selain itu, menurut pengamatan petani dan peneliti di lapangan, buah kakao pada tanaman yang diberikan pupuk tersebut menjadi lebih bersih mengilat, tidak kusam dan berbintik-bintik seperti sebelumnya. Keuntungan lainnya yang mendorong petani untuk mau menerapkan teknologi ini adalah karena rendahnya biaya yang dibutuhkan untuk membuat pupuk tersebut, serta bahanbahan yang dibutuhkan pun mudah didapatkan.

\section{Perilaku Petani dalam menerapkan teknologi BP3T pupuk kandang untuk tanaman kakao di Kabupaten Limapuluh Kota}

Menurut Marzuki (1999), perilaku adalah semua tingkah laku manusia yang hakekatnya mempunyai motif, yaitu meliputi pengetahuan, sikap, dan keterampilan. Kegiatan manusia dapat bermotif tunggal ataupun ganda. Biasanya perbuatan tersebut terdorong oleh suatu motif utama dan beberapa motif pendukung yang merupakan rincian dari motif utama. Dalam pembangunan pertanian, pengetahuan petani mempunyai arti penting karena dapat meningkatkan kemampuannya untuk mengadopsi teknologi baru di bidang pertanian. Jika pengetahuan petani tinggi dan petani bersikap positif terhadap suatu teknologi baru di bidang pertanian, maka penerapan teknologi tersebut akan menjadi lebih sempurna, yang pada akhirnya akan memberikan hasil secara lebih memuaskan baik secara kuantitas maupun kualitas (Sudarta, 2005).

Dalam penelitian ini, pengetahuan petani diukur dari pengetahuan petani tentang pengaruh pupuk secara umum terhadap tanaman kakao, pengadaan pupuk oleh petani, pengetahuan petani mengenai produksi kakao yang dihasilkan dengan menggunakan pupuk biasa. Sementara itu, sikap petani diukur dengan keingintauan petani terhadap teknologi, keingintahuan terhadap alat dan bahan yang diperlukan untuk membuat teknologi tersebut, dan keinginan petani menerapkan teknologi BP3T pupuk kandang secara berkelanjutan di lahan usahatani kakao mereka. Sedangkan keterampilan petani dilihat dari kemampuan petani dalam melakukan dan mengulangi kembali semua prosedur pembuatan BP3T pupuk kandang. Tabel 3 memperlihatkan distribusi perilaku petani kakao di Kabupaten Limapuluh Kota yang meliputi pengetahuan dan sikap petani kakao dalam menerapkan teknologi BP3T pupuk kandang untuk tanaman kakao.

Berdasarkan Tabel 3, umumnya anggota kelompok tani menyatakan bahwa pertumbuhan kakao dipengaruhi oleh pupuk. Menurut anggota kelompok, tanpa pemupukan yang baik, maka pertumbuhan kakao tidak akan maksimal. Hal ini telah dibuktikan oleh anggota kelompok, seperti petani pada kelompok tani Aroma, di mana terdapat perbedaan yang cukup signifikan pada tanaman kakao sebelum dan sesudah dipupuk dengan baik, sebab sebelum tergabung ke dalam kelompok, petani umumnya tidak benar-benar merawat tanaman kakao mereka termasuk tidak melakukan pemupukan, sehingga pertumbuhan batang maupun buahnya tidak maksimal. Akan tetapi, setelah tergabung ke dalam kelompok, petani mulai rajin merawat dan melakukan pemupukan terhadap tanaman kakao mereka. Meskipun demikian, hasilnya masih belum terlalu optimal walau pertumbuhannya sudah lebih baik. Jenis pupuk yang digunakan oleh petani umumnya merupakan campuran antara pupuk kimia sintetis dan pupuk kandang. Pupuk kimia sintetis umumnya didapatkan dengan membeli di agen pupuk, sedangkan pupuk kandang diperoleh petani dengan dibeli dan dari ternak sendiri.

Hasil penelitian pada Tabel 3 juga menunjukkan bahwa petani umumnya ingin tahu terhadap paket teknologi formula BP3Tpupuk kandang sapi yang dilakukan selama 
Tabel 3. Distribusi perilaku petani kakao dalam menerapkan teknologi BP3T pupuk kandang pada kelompok tani di Kabupaten Limapuluh Kota

\begin{tabular}{|c|c|c|c|c|c|c|c|c|c|}
\hline \multirow{2}{*}{\multicolumn{2}{|c|}{$\begin{array}{c}\text { Frekuensi } \\
\text { Karakteristik } \\
\text { Inovasi Pupuk } \\
\end{array}$}} & \multicolumn{4}{|c|}{ Frekuensi (jumlah orang) } & \multicolumn{4}{|c|}{ Persentase (\%) } \\
\hline & & \multirow[t]{2}{*}{ Aroma } & \multirow[t]{2}{*}{ Inovasi } & \multirow[t]{2}{*}{$\begin{array}{l}\text { Buah } \\
\text { Lobek }\end{array}$} & \multirow[t]{2}{*}{$\begin{array}{c}\text { Maju } \\
\text { Sejahtera } \\
\end{array}$} & \multirow[t]{2}{*}{ Aroma } & \multirow[t]{2}{*}{ Inovasi } & \multirow[t]{2}{*}{$\begin{array}{c}\text { Buah } \\
\text { Lobek }\end{array}$} & \multirow[t]{2}{*}{$\begin{array}{c}\text { Maju } \\
\text { Sejahtera }\end{array}$} \\
\hline 1. & $\begin{array}{l}\text { Pengaruh } \\
\text { Pupuk }\end{array}$ & & & & & & & & \\
\hline & Tidak & 0 & 0 & 2 & 0 & 0 & 0 & 16.7 & 0 \\
\hline & Ya & 12 & 8 & 10 & 11 & 100.0 & 100.0 & 83.3 & 100.0 \\
\hline \multirow[t]{4}{*}{2.} & $\begin{array}{l}\text { Pengadaan } \\
\text { Pupuk }\end{array}$ & & & & & & & & \\
\hline & Tidak & 1 & 0 & 1 & 1 & 8.3 & 0 & 8.3 & 9.1 \\
\hline & Beli & 11 & 8 & 11 & 10 & 91.7 & 100.0 & 91.7 & 90.9 \\
\hline & Buat sendiri & 0 & 0 & 0 & $\mathbf{0}$ & 0 & 0 & 0 & $\mathbf{0}$ \\
\hline \multirow[t]{3}{*}{3.} & $\begin{array}{l}\text { Produksi dari } \\
\text { pupuk biasa }\end{array}$ & & & & & & & & \\
\hline & Tidak meningkat & 1 & 0 & 1 & 3 & 8.3 & 0 & 8.3 & 27.3 \\
\hline & Meningkat/Baik & 11 & 8 & 11 & 8 & 91.7 & 100.0 & 91.7 & 72.7 \\
\hline \multirow[t]{3}{*}{4.} & $\begin{array}{l}\text { Keingintahuan } \\
\text { terhadap inovasi }\end{array}$ & & & & & & & & \\
\hline & Tidak Ingin tahu & 0 & 0 & 0 & 0 & 0 & 0 & 0 & 0 \\
\hline & Ingin tahu & 12 & 8 & 12 & 11 & 100.0 & 100.0 & 100.0 & 100.0 \\
\hline \multirow[t]{3}{*}{5.} & $\begin{array}{l}\text { Bahan baku } \\
\text { inovasi }\end{array}$ & & & & & & & & \\
\hline & Tidak Tahu & 0 & 0 & 0 & 0 & 0 & 0 & 0 & 0 \\
\hline & Tahu & 12 & 8 & 12 & 11 & 100.0 & 100.0 & 100.0 & 100.0 \\
\hline \multirow[t]{3}{*}{6.} & Alat inovasi & & & & & & & & \\
\hline & Tidak Tahu & 0 & 0 & 0 & 0 & 0 & 0 & 0 & 0 \\
\hline & Tahu & 12 & 8 & 12 & 11 & 100.0 & 100.0 & 100.0 & 100.0 \\
\hline \multirow[t]{4}{*}{7.} & $\begin{array}{l}\text { Keinginan } \\
\text { menerapkan }\end{array}$ & & & & & & & & \\
\hline & Tidak & 0 & 0 & 12 & 0 & 0 & 0 & 0 & 0 \\
\hline & Ya & 12 & 8 & 0 & 11 & 100.0 & 100.0 & 100.0 & 100.0 \\
\hline & Jumlah & 12 & 8 & 12 & 11 & 100.0 & 100.0 & 100.0 & 100.0 \\
\hline
\end{tabular}

pelatihan, sebab umumnya petani tahu mengenai manfaat pupuk tersebut. Menurut petani, beberapa manfaat yang dihasilkan oleh pupuk kandang tersebut terhadap tanaman kakao adalah pertumbuhan menjadi lebih baik, munculnya tunas-tunas daun baru, daun menjadi hijau dan mengilat, dan memacu pertumbuhan bunga dan putik kakao. Selain itu, keuntungan yang diperoleh petani adalah biaya pemupukan kakao per batang dengan menggunakan teknologi BP3T-pupuk kandang sapi lebih rendah dibandingkan dengan biaya pemupukan menggunakan pupuk kandang biasa dan pupuk kimia sintetis.

Umumnya petani mengetahui bahan baku dan alat yang harus digunakan untuk membuat formula BP3T pupuk kandang sapi. Bahan baku yang digunakan adalah pupuk kandang sapi, air kelapa, gula, dan biang bakteri yang didapatkan dari peneliti. Sementara itu, alat yang digunakan terdiri atas galon, aerator, selang ukuran kecil, dan terpal. Petani juga umumnya tahu cara membuat teknologi tersebut, dengan kata lain mereka memiliki telah keterampilan dalam membuat teknologi BP3T pupuk kandang. Menurut petani, cara membuat pupuk kandang tersebut yaitu pupuk kandang disebarkan dengan rata di atas terpal, lalu disiram dengan fermentasi air kelapa yang sudah dimasukkan biang bakteri, kemudian diaduk sampai rata. Setelah itu, pupuk kandang kembali disirami air fermentasi kepala dan kembali diaduk, demikian seterusnya hingga fermentasi air kepala sesuai dosis habis. Setelah pupuk 
Tabel 4. Nilai koefisien chi square antara karakteristik petani dengan perilaku petani kakao dalam menerapkan teknologi BP3T pupuk kandang pada kelompok tani di Kabupaten Limapuluh Kota

\begin{tabular}{|c|c|c|c|c|c|c|c|c|}
\hline \multirow{2}{*}{\multicolumn{2}{|c|}{$\begin{array}{c}\text { Karakteristik Petani } \\
\text { Kakao }\end{array}$}} & \multicolumn{7}{|c|}{ Perilaku petani kakao } \\
\hline & & $\begin{array}{l}\text { Pengaruh } \\
\text { pupuk }\end{array}$ & $\begin{array}{l}\text { Pengadaa } \\
\text { n pupuk }\end{array}$ & $\begin{array}{l}\text { Produksi } \\
\text { dg pupuk } \\
\text { biasa }\end{array}$ & $\begin{array}{l}\text { Keingint } \\
\text { ahuan } \\
\text { thd } \\
\text { inovasi }\end{array}$ & $\begin{array}{l}\text { Bahan } \\
\text { Baku } \\
\text { inovasi }\end{array}$ & $\begin{array}{l}\text { Alat } \\
\text { inovasi }\end{array}$ & $\begin{array}{c}\text { Keingina } \\
\mathrm{n} \\
\text { menerap } \\
\text { kan }\end{array}$ \\
\hline 1. & Umur & 0.248 & 0.282 & 0.465 & $0.005^{* *}$ & 0.177 & $0.005^{* *}$ & 0.521 \\
\hline 2. & $\begin{array}{l}\text { Tingkat pendidikan } \\
\text { formal }\end{array}$ & 0.141 & 0.866 & 0.392 & 0.385 & 0.141 & 0.385 & 0.641 \\
\hline 3. & $\begin{array}{l}\text { Tingkat pendidikan } \\
\text { nonformal }\end{array}$ & 0.782 & 0.225 & 0.821 & 0.955 & 0.164 & 0.955 & 0.760 \\
\hline 4. & $\begin{array}{l}\text { Pengalaman } \\
\text { berusaha tani }\end{array}$ & 0.298 & 0.336 & 0.657 & 0.253 & 0.298 & 0.253 & 0.532 \\
\hline 5. & Pekerjaan utama & 0.120 & 0.639 & 0.206 & 0.345 & 0.177 & 0.345 & 0.278 \\
\hline 6. & $\begin{array}{l}\text { Status lahan } \\
\text { usahatani }\end{array}$ & 0.823 & 0.962 & $0.005^{* *}$ & 0.876 & 0.823 & 0.876 & 0.876 \\
\hline 7. & Luas lahan & 0.441 & 0.827 & 0.669 & 0.612 & 0.166 & 0.612 & 0.869 \\
\hline & Jenis kelamin & 0.314 & 0.291 & 0.524 & 0.482 & 0.314 & 0.482 & 0.145 \\
\hline
\end{tabular}

kandang diaduk rata dengan ferementasi air kelapa, selanjutnya pupuk tersebut ditutup kembali dengan terpal dan didiamkan selama satu bulan. Lima belas hari kemudian, pupuk kandang harus dibuka dan diaduk kembali, kemudian kembali ditutup dan didiamkan selama lima belas hari. Setelah itu, pupuk siap digunakan.

Petani kelompok tani kakao di Kabupaten Limapuluh Kota umumnya memiliki keinginan untuk menerapkan teknologi formula BP3T untuk lahan mereka sendiri. Hal ini disebabkan karena keuntungan yang didapatkan, yaitu tanaman kakao menjadi lebih baik, mengurangi penyakit VSD yang rentan menyerang tanaman kakao petani, dan merangsang pertumbuhan tunas daun baru serta bunga baru yang kemudian tumbuh menjadi putik dan buah. Selain itu, menurut pengamatan petani dan peneliti di lapangan, buah kakao pada tanaman yang diberikan pupuk tersebut menjadi lebih bersih mengilat, tidak kusam dan berbintik-bintik seperti sebelumnya. Keuntungan lainnya yang mendorong petani untuk mau menerapkan teknologi ini adalah karena rendahnya biaya yang dibutuhkan untuk membuat pupuk 211 tersebut, serta bahan-bahan yang dibutuhkan pun mudah didapatkan.

\section{Hubungan Karakteristik Petani terhadap Perilaku Petani Kakao dalam Menerapkan Teknologi BP3T Pupuk Kandang untuk Tanaman Kakao di Kabupaten Limapuluh Kota}

Karakteristik pada individu petani umumnya berbeda-beda. Manyamsari dan Mujiburrahmad (2014) menyebutkan bahwa sebagai manusia yang hidup bermasyarakat, petani memiliki kebebasan untuk berinteraksi dengan lingkungan di sekitarnya, mempelajari berbagai hal baru, dan mengikuti setiap perkembangan yang ada sehingga akan membentuk karakteristik petani yang berhubungan dengan kemampuan mereka dalam berusahatani. Karakteristik ini akan mencerminkan perilaku petani dalam berusahatani. Analisis chi square pada Tabel 4 menunjukkan hubungan antara karakteristik petani yang terdiri atas umur, tingkat pendidikan formal, tingkat pendidikan nonformal, pengalaman berusahatani, pekerjaan utama, status lahan, luas lahan, dan jenis kelamin dengan perilaku petani kakao yang terdiri atas pengaruh pupuk, pengadaan 
pupuk, produksi dengan pupuk biasa, keingintahuan terhadap inovasi, bahan baku inovasi, alat inovasi, dan keinginan menerapkan inovasi teknologi BP3T pupuk kandang pada kelompok tani di Kabupaten Limapuluh Kota.

Hasil penelitian pada Tabel 4 menunjukkan bahwa terdapat hubungan nyata kuat pada taraf signifikan 0.1 antara umur petani dan keingintahuan terhadap inovasi dan pengetahuan petani terhadap alat-alat yang digunakan untuk membuat teknologi BP3T pupuk kandang. Sejalan dengan Mulyasa (2003) yang menyatakan bahwa perkembangan kemampuan berpikir terjadi seiring bertambahnya umur, maka semakin tua umur petani kakao dalam penelitian ini, maka keingintahuan petani terhadap inovasi semakin tinggi. Lebih jauh, hasil penelitian Senyolo et al. (2017) dan Ilori et al. (2017) menyebutkan bahwa karakteristik petani seperti umur dan preferensi petani mempengaruhi kemampuan mereka dalam menerapkan inovasi.

Demikian juga halnya dengan pengetahuan petani terhadap alat-alat yang digunakan untuk membuat pupuk kandang tersebut, di mana semakin tua umur petani, maka pengetahuan petani terhadap jenis alat yang digunakan semakin baik. Keingintahuan petani yang tinggi tersebut disebabkan karena pengalaman petani yang sudah lama berusahatani, seperti halnya yang dinyatakan oleh Manyamsari dan Mujiburrahmad (2014). Berdasarkan hasil wawancara dengan petani, keinginan petani untuk mengetahui teknologi tersebut untuk memperbaiki usahatani kakao mereka sehingga hasilnya dapat meningkat, yang mana pada akhirnya juga ikut meningkatkan produksi untuk pendapatan yang lebih banyak. Hal ini dipertegas dengan hasil penelitian Farid et al. (2018) bahwa faktor umur memengaruhi petani untuk semakin meningkatkan kemampuan usahataninya untuk meningkatkan kebutuhan hidup.

Namun, umumnya hasil penelitian pada Tabel 4 menunjukkan bahwa tidak terdapat hubungan pada taraf nyata 90\% antara karakteristik individu petani kakao dengan perilaku petani kakao dalam menerapkan teknologi BP3T pupuk kandang pada kelompok tani di Kabupaten Limapuluh Kota, artinya bahwa umumnya karakteristik petani tidak berhubungan dengan perilaku petani dalam menerapkan teknologi BP3T pupuk kandang di Kabupaten Limapuluh Kota. Tidak selamanya karakteristik petani berhubungan dengan perilaku petani dalam menerapkan teknologi BP3T pupuk kandang di Kabupaten Limapuluh Kota. Menurut Lalla et al. (2012) dan dan Tanjung et al. (2017) bahwa karakteristik petani seperti umur, tingkat pendidikan, dan luas lahan tidak selamanya berhubungan dengan adopsi inovasi, karena pengalaman berusaha tani, status dalam kelompok serta status sosial di masyarakat turut mempengaruhi adopsi suatu inovasi. Karakteristik petani seperti pendidikan formal, pendidikan nonformal, status lahan usahatani, dan luas lahan usahatani tidak selamanya berhubungan dengan petani kakao dalam menerapkan paket teknologi BP3T pupuk kandang.

Penjelasan tersebut juga dipertegas oleh Sadono et al (2014); dan Ajak dan Demiryurek (2017) bahwa karakteristik individu seperti umur, pengalaman berusaha tani, luas lahan, hingga tingkat pendapatan petani tidak berhubungan dan tidak berpengaruh terhadap pemberdayaan petani, akses informasi, atau bahkan diskriminasi sosial petani. Menegaskan hal tersebut, Malta (2016) juga menyebutkan bahwa tidak terdapat hubungan antara pendidikan formal dan pengalaman berusaha tani dengan kemandirian petani dalam perilaku petani untuk melanjutkan usahatani. Berdasarkan penjelasan tersebut, dapat disimpulkan bahwa karakteristik petani seperti tingkat pendidikan formal, tingkat pendidikan nonformal, status kepemilikan lahan dan luas lahan tidak selamanya berpengaruh terhadap penerapan inovasi teknologi BP3T pupuk kandang karena meskipun petani tidak memiliki pendidikan formal hingga SMA atau S1, memiliki lahan pribadi atau sewa dengan luas 
lahan sempit, petani tetap menerapkan teknologi BP3T pupuk kandang untuk tanaman kakao mereka.

\section{Hubungan Karakteristik Inovasi terhadap Perilaku Petani Kakao Dalam Menerapkan Teknologi BP3T Pupuk Kandang untuk Tanaman Kakao di Kabupaten Limapuluh Kota}

Menurut Rogers (2013), Meulen et al. (2016), dan Senyolo et al. (2017) karakteristik inovasi berhubungan dengan perilaku petani dalam mengadopsi dan keberlanjutan penerapan suatu inovasi. Namun, selain mendorong kecepatan adopsi inovasi, berbagai karakteristik inovasi tersebut juga dapat menghambat adopsi inovasi (Warnaen et al. 2013). Berdasarkan analisa rank Spearman seperti yang terlihat pada Tabel 5, umumnya terdapat hubungan nyata pada taraf signifikan 0,1 antara karakteristik inovasi teknologi BP3T pupuk kandang dan perilaku petani kakao dalam menerapkan teknologi tersebut di Kabupaten Limapuluh Kota. Lebih lanjut, Tabel 5 juga memperlihatkan bahwa indikator karakteristik inovasi yang terdiri atas keuntungan relatif, tingkat kesesuaian, kendala inovasi, tingkat kemudahan, dan tingkat keteramatan inovasi umumnya memiliki hubungan nyata yang cukup kuat dengan indikator perilaku petani kakao dalam menerapkan teknologi BP3T pupuk kandang.

Hasil penelitian pada Tabel 5 memperlihatkan bahwa karakteristik inovasi teknologi BP3T pupuk kandang berhubungan nyata pada taraf

Tabel 5.Koefisien korelasi rank Spearman antara karakteristik inovasi teknologi BP3T pupuk kandang terhadap teknologi BP3T pupuk kandang di Kabupaten Limapuluh Kota

\begin{tabular}{|c|c|c|c|c|c|c|c|}
\hline \multirow[b]{2}{*}{$\begin{array}{c}\text { Karakteristik Petani } \\
\text { Kakao }\end{array}$} & \multicolumn{7}{|c|}{ Perilaku petani kakao } \\
\hline & $\begin{array}{l}\text { Pengaruh } \\
\text { pupuk }\end{array}$ & $\begin{array}{l}\text { Pengadaan } \\
\text { pupuk }\end{array}$ & $\begin{array}{c}\text { Produksi } \\
\text { dg } \\
\text { pupuk } \\
\text { biasa }\end{array}$ & $\begin{array}{l}\text { Keingintahuan } \\
\text { thd inovasi }\end{array}$ & $\begin{array}{c}\text { Bahan } \\
\text { Baku } \\
\text { inovasi }\end{array}$ & $\begin{array}{l}\text { Alat } \\
\text { inovasi }\end{array}$ & $\begin{array}{l}\text { Keinginan } \\
\text { menerapkan }\end{array}$ \\
\hline $\begin{array}{l}\text { 1. } \begin{array}{l}\text { Keuntungan } \\
\text { relatif }\end{array} \\
\text { ret }\end{array}$ & -0.080 & $0,302^{*}$ & $0,774^{* *}$ & $0,425^{* *}$ & $0.383^{* *}$ & $0,425^{* *}$ & $0,358^{*}$ \\
\hline $\begin{array}{l}\text { 2. Tingkat } \\
\text { kesesuaian }\end{array}$ & $0.268^{*}$ & $0.279^{*}$ & $0.254^{*}$ & $0.358^{*}$ & $0.301^{*}$ & $0.272^{*}$ & $0.294^{*}$ \\
\hline $\begin{array}{l}\text { 3. Tingkat } \\
\text { kemudahan }\end{array}$ & $0,330^{*}$ & $0,288^{*}$ & $0,315^{*}$ & $0,309^{*}$ & $0,348^{*}$ & $0,330^{*}$ & $0,288^{*}$ \\
\hline $\begin{array}{l}\text { 4. Tingkat } \\
\text { keteramatan }\end{array}$ & $0,441^{* *}$ & $0,285^{*}$ & $0,633^{* *}$ & $0,482^{* *}$ & $0,441^{* *}$ & $0,482^{* *}$ & $0.372^{* *}$ \\
\hline 5. Kendala inovasi & $490^{* *}$ & .141 & .083 &, $435^{* *}$ &, $377^{* *}$ &, $490^{* *}$ & .141 \\
\hline
\end{tabular}

${ }^{* *}$.Correlation is significant at the 0.01 level (2-tailed) ${ }^{*}$.Correlation is significant at the 0.05 and 0.1 level (2tailed)

signifikan 0.1 dengan perilaku petani untuk menerapkan teknologi tersebut di lahan kakao mereka. Salah satunya pada indikator keuntungan relatif teknologi BP3T pupuk kandang yang berhubungan dengan pengadaan pupuk, produksi kakao dengan menggunakan pupuk biasa, keingintahuan terhadap inovasi, pengetahuan terhadap bahan baku dan alat inovasi, serta keinginan untuk menerapkan teknologi BP3T pupuk kandang. Hal tersebut seperti halnya hasil penelitian Ridwan et al. (2010) tentang teknologi PTKJS (Pengelolaan Terpadu Kebun Jeruk Sehat) dan Anggreany et al. (2016) tentang inovasi replanting kelapa sawit, yang menyatakan bahwa berbagai keunggulan dan keuntungan relatif inovasi teknologi yang diberikan turut mendorong petani dalam mengadopsi suatu inovasi. Berbagai keuntungan yang didapatkan petani 
kakao dari teknologi BP3T pupuk kandang seperti perbaikan terhadap kondisi daun, batang, dan buah; serta lebih rendahnya biaya produksi teknologi BP3T pupuk kandang dibandingkan pupuk jenis lain juga mendorong petani untuk lebih memilih menggunakan teknologi BP3T pupuk kandang untuk pemupukan dibandingkan dengan jenis pupuk lainnya. Selain itu, temuan juga menunjukkan bahwa keuntungan relatif.

Berbagai keuntungan tersebut mendorong petani terhadap perilaku mereka untuk menambah pengetahuan mengenai teknologi BP3T pupuk kandang. Wayan dan Mowidu (2010) menyatakan bahwa berbagai pengetahuan petani memengaruhi perilaku petani dalam menerapkan inovasi. Pengetahuan mengenai keuntungan teknologi BP3T pupuk kandang semakin mendorong keinginan petani kakao untuk mencoba pada skala kecil dan menerapkan teknologi tersebut pada lahan usahatani kakao mereka.

Tabel 5 juga menunjukkan bahwa kesesuaian sumberdaya yang dimiliki petani dengan teknologi yang diberikan, kemudahan penerapan teknologi, dan kemampuan hasil dari teknologi untuk diamati perkembangan dan pertumbuhannya turut berperan terhadap perilaku petani kakao dalam menerapkan teknologi BP3T pupuk kandang. Hal tersebut seperti halnya temuan Edwina dan Maharani (2010), Sadikin (2013), Fachrista dan Sarwendah (2014), dan Sholahuddin et al. (2017) yang mengemukakan bahwa suatu inovasi yang memiliki keuntungan, mudah untuk diterapkan dan diamati, serta semakin sesuai dengan kebutuhan petani, maka akan semakin mudah pula petani mengadopsi suatu inovasi. Akses sumberdaya yang murah dan mudah diakses seperti air kepala, pupuk kandang sapi, dan galon; petani dapat membuat pupuk tersebut secara pribadi tanpa bantuan kelompok atau peneliti; dan hasil yang telah terbukti baik mendorong keinginan petani untuk menggunakan teknologi tersebut pada lahan usahatani kakao mereka.

\section{Kesimpulan}

Umumnya petani kakao di Kabupaten Limapuluh Kota berjenis kelamin laki-laki, berusia 30-49 tahun, tingkat pendidikan formal SMA - Perguruan Tinggi, mengikuti pendidikan nonformal 1-2 kali, pengalaman berusahatani kakao 1-10 tahun, lahan merupakan milik sendiri dengan luas lahan 0.2 - 0.7 ha, dan pekerjaan utama sebagai petani kakao. Karakteristik inovasi menunjukkan bahwa umumnya mengetahui manfaat paket teknologi formula BP3Tpupuk kandang sapi, teknologi sesuai dengan sumberdaya yang dimiliki petani dan mudah dikerjakan, dan tidak ada kendala berarti dalam menerapkannya. Perilaku petani menunjukkan bahwa petani mengetahui pengaruh pupuk secara umum terhadap tanaman, pupuk didapatkan dari agen pupuk atau diproduksi sendiri, hasil dengan pemupukan sintetis dan pupuk kandang biasa cukup baik meski tidak optimal, petani ingintahu terhadap teknologi BP3T pupuk kandang, serta cara membuat dan menerapkan serta alat-alat dan bahan yang diperlukan.

Petani umumnya menunjukkan perilaku berupa sikap ingin menerapkan paket teknologi BP3T pupuk kandang dalam jangka panjang. Secara umum hal tersebut didukung oleh karakteristik inovasi yang memiliki keunggulan dan keuntungan, sumberdaya yang mudah diakses, teknologi mudah dikerjakan dan diterapkan, hasil dapat diamati, dan tidak ada kendala berarti. Namun, keinginan tersebut secara umum tidak berhubungan dengan karakteristik individu petani yang terdiri atas pendidikan formal, pendidikan nonformal, pengalaman berusahatani, status lahan, luas lahan, pekerjaan utama, dan jenis kelamin.

\section{Daftar Pustaka}

Ajak, J. D. A.,dan Demiruyek, K. 2017. Agricultural Innovation System: Case of Cassava Producers in Kajo-Keji, South Sudan. American Journal of Agriculture and Forestry. 5(4): 94-101. 
Anggreany, S., Muljono, P., dan Sadono, D. 2016. Partisipasi Petani dalam Replanting Kelapa Sawit di Provinsi Jambi. Jurnal Penyuluhan. 12(1): 1-14.

Azwar. 2000. Sikap Manusia, teori dan Pengukurannya. Pustaka Pelajar Offset. Yogyakarta.

Edwina, S., dan Maharani, T. 2010. Persepsi Petani terhadap Inovasi Teknologi Pengolahan Pakan Ternak di Kecamatan Kerinci Kanan Kabupaten Siak. Indonesian Journal of Agriculture Economis. 2, 170-183

Fachrista, I. A., dan Sarwendah, M. 2014. Persepsi dan Tingkat Adopsi Petani Terhadap Inovasi Teknologi Pengelolaan Tanaman Terpadu Padi Sawah. Agriekonomika. 3(1): 1-10.

Farid, A., Romadi, U., dan Witono, D. 2018. Faktor-Faktor yang Mempengaruhi Adopsi Petani dalam Penerapan Sistem Tanam Jajar Legowo di Desa Sukosari Kecamatan Kasembon Kabupaten Malang Provinsi Jawa Timur. Jurnal Penyuluhan. 14(1): 27-32.

Ilori, A. B., Lawal A. F., dan Oke S. 2017. Effect of Socio-Economics Characteristics, Production and Innovation Capabilities on the Performance of Palm Kernel Processing Firms in South-western Nigeria. IJERMT. 6(1): 88-95.

Lalla, H., Ali, M. S. S., dan Saadah. 2012. Adopsi Petani Padi Sawah Terhadap Sistem Tanam Jajar Legowo 2:1 di Kecamatan Polongbangkeng Utara, Kabupaten Takalar.J Sains \& Teknologi. 12(3): 225-264.

Malta. 2016. Faktor-faktor yang Berhubungan dengan Kemandirian Petani dalam Pengambilan Keputusan untuk Keberlanjutan Usahatani (Kasus: Petani di Desa Sukaharja - Kabupaten Bogor).Sosiohumaniora.18(2): 118124.

Manyamsari, I., Mujiburrahmad. 2014. Karakteristik Petani Dan Hubungannya
Dengan Kompetensi Petani Lahan Sempit (Kasus : Di Desa Sinar Sari Kecamatan Dramaga Kab. Bogor Jawa Barat). Agrisep. 15(2): 58-74.

Mariana M dan Noveriza R. 2013. Potensi minyak atsiri untuk mengendalikan Potyvirus pada Tanaman Nilam. Jurnal Fitopatologi Indonesia. 9(1):53-58. DOI: 10.14692/jfi.9.2.53

Marzuki, S. 1999. Dasar-dasar Penyuluhan Pertanian; Materi Pokok LUTH4211. Cetakan 1- 9. Jakarta (ID): Universitas Terbuka.

Meulen, H. V. D., Assseldonk, M. V., dan Ge ,L. 2016. Adoption of Innovation in European Agriculture. Europe.

Ridwan, H.K., Sabari, Rofik, S.B., Rahman, S., dan Agus, R. 2010. Adopsi Inovasi Teknologi Pengelolaan Terpadu Kebun Jeruk Sehat (PTKJS) di Kabupaten Ponorogo, Jawa Timur. J Hort. 20(1): 96-102.

Rogers, E. 2003. Diffusion of Innovations Fifth Edition. New York (AS): The Free Pr.

Sadikin, I. 2013. Pengaruh Faktor Sosial Ekonomi Terhadap Adopsi PTT di Sentra Padi Jawa Barat. Agros.15(1): 123-136.

Sadono, D., Sumardjo, Gani, D. S., dan Amanah, S. 2014. Farmer Empowerment in The Management of Rice Farming in Two Districts. Journal of Rural Indonesia. 2 (1): 105 - 126.

Sarwono, S. 1993. Sosiologi Kesehatan. Yogyakarta: Gadjah Mada University Press

Senyolo, M. P., Long, T. B., Blok, V., dan Omta, O. 2017. How the characteristics of innovations impact their adoption: An exploration of climate-smart agricultural innovations in South Africa. Journal of Cleaner Production. 30: 1-16.

Sholahuddin, Setyawan, A. A., dan Trisnawati, R. 2017. Pengaruh Karakteristik Inovasi terhadap Niat 
Mengadopsi Solopos Epaper. Prosiding Semnas Riset Manajemen \& Bisnis. 6384.

Sudarta, W. 2005. Pengetahuan dan Sikap Petani Terhadap Pengendalian Hama Tanaman Terpadu (Online). http: //ejournal .unud. ac.id/abstrak / (6)\%20soca-sudarta-pks\%20pht(2).pdf diakses 30 Desember2009.

Tanjung, N.S., Sadono, D., Wibowo, C.T. 2017. Tingkat Partisipasi Masyarakat dalam Pengelolaan Hutan Nagari di Sumatera Barat. Jurnal Penyuluhan. 13(1): 14-30.

Trisno, J, Habaza, T, Jamsari dan Hidayat SH. 2013.Penapisan kemampuan isolatrizobakteri indigenus dalam meningkatkan ketahanan tanaman cabai terhadap penyakit virus daun kuning keriting. Prosiding Seminar Nasional dan Rapat tahunan dekan bidang ilmu pertanian BKS wilayah Barat. Pontianak 14 - 20 Maret 2013: 889902.

Warnaen, A., Cangara, H., dan Bulkis, S. 2013. Faktor-Faktor yang Menghambat Inovasi pada Komunitas Petani dan Nelayan dalam Meningkatkan Kesejahteraan Masyarakat di Kabupaten Takalar. KAREBA. 2(3): 241-249.

Wayan, I., dan Mowidu, I. 2010. Perilaku Petani dalam Konservasi Lahan pada Usahatani Kakao di Kecamatan Poso Pesisir Utara. Media Litbang Sulteng. 3(1): 38-43. 